have revealed the presence of bony changes which had been barely visible in previous radiographs. This may reflect the clinicians' poor prediction rather than radiological technique. On occasion, while scanning one area under suspicion another, totally unexpected, area will appear active, and when this is examined radiologically the bony changes are apparent. In this situation scanning has supplemented but in no way replaced radiology.

Because of the limited areas scanned in this group of patients, coupled with the frequent occurrence of crush and healing fractures, the biochemical indices of overall bone diseases are difficult to compare with the scanning results. In three patients increased excretion of hydroxyproline containing peptides was the only positive biochemical finding which correlated with a positive scan, and this finding needs to be confirmed in a larger series.

Malignancy was suspected in three patients, but biopsy in one showed a tuberculous abscess and in the other two the symptoms receded with antibiotic therapy-a reminder that not all vertebral disease in patients with a past history of malignant disease need be metastatic.

The initial study was made possible by a B.M.A. research award which was used to provide a simple scanning system. The extension of the project was only possible by the generous provision by the British Empire Cancer Campaign of the Picker Magna Scanner in use at King's College Hospital. Research funds from King's College Hospital helped to staff the scanning-room. We are indebted to Dr. Brian Keane, Dr. E. Millington, and Dr. J. G. de Winter at the Royal Sussex County Hospital for facilities in the Department of Physics and Radiotherapy, and to Mr. Neville Screech for technical help. We should like to thank the many physicians and surgeons at both hospitals who referred patients for the investigations. We are grateful to Professor John Anderson, Dr. Sidney Osborn, and Dr. Vera Dalley for their interest, discussion, and criticism throughout this project.

\section{REFERENCES}

Bauer, G. C. H., Carlsson, A., and Lindquist, B. (1958). In Radioaktive Isotope in Klinik und Forschung, vol. 3, p. 25, edited by K. Fellinger and $\mathrm{H}$. Vetter. Munich and Berlin.

Bauer, G. C. H., and Scoccianti, P. (1961). Acta orthop. scand., 31, 90. Bauer, G. C. H. and Wendebergh, B. (1959). 7. Bone Ұt Surg., 41B, 558. Bessler, W. T. (1968). Amer. F. Roentgenol., 102, 899.

Blau, M., Laor, Y., and Bender, M. A. (1963). F. nucl. Med., 4, 193.

Charkes, N. D., Sklaroff, D. M., and Bierly, J. (1964). Amer. Ұ. Roentgenol., 91, 1121.

Charkes, N. D., Sklaroff, D. M., and Young, I. (1966). Amer. F. Roentgenol., 96, 647

Corey, K. R., Kenny, P., Greenberg, E., Pazianos, A., Pearson, O. H., and Laughlin, J. S. (1961). Amer. F. Roentgenol., 85, 955.

Corey, K. R., Kenny, P., Greenberg, E., and Laughlin, J. S. (1962). F. nucl. Med., 3, 454 .

DeNardo, G. L., and Volpe, J. A. (1966). 7. nucl. Med., 7, 219.

Fiske, C. H.; and Subbarow, Y. (1925). 7. biol. Chem., 66, 375

Follis, R. H. (1950). Metabolic Interrelations. Transactions of Second Conference, edited by E. C. Reifenstein, jun., p. 221. New York.

French R. I., and McCreadv V. R. (1967). Brit. F. Radiol., 40, 655.

Greenberg, E. J., Rothschild, E. O., DePalo, A., and Laughlin, J S. (1966). Med. clin. N. Amer., 50, 701.

Gynning, I., Langeland, P., Lindberg, S., and Waldeskog, B. (1961). Acta radiol. (Stockh.), 55, 119.

Kampffmeyer, H. G., Dworkin, H., Carr, E. A., and Bull, F. E. (1967). Clin. Pharmacol. Ther., 8, 647.

King, E. J., and Armstrong, A. R. (1934). Canad. med. Ass., f., 31, 376. Lachman, E. (1955). Amer. F. Roentgenol., 74, 712.

Laughlin, J S., Kenny, P. J., Corey, K. R., Greenberg, E., and Weber, D. A. (1964). In Medical Radioisotope Scanning, vol. 1, p. 253. Vienna.

MacIntyre, I. (1961). Advanc. clin. Chem., 4, 1.

Moon, N. F., Dworkin, H. J., and Lafluer, P. D. (1968). F. Amer. med. Ass., $204,974$.

Prockop, D. J., and Udenfriend, S. (1960). Analyt. Biochem., 1, 228.

Rosenthal, L. (1964). F. Canad. Ass. Radiol., 15, 53.

Rosenthal, L. (1965). Radiology, 84, 75.

Sanguinetti, M. (1968). Tumori, 54, 175.

Sklaroff, D. M., and Charkes, N. D. (1967). Amer. F. Roentgenol., 99, 415

Spencer, R., Herbert, R., Rish, M. W., and Little, W. A. (1967). Brit. F. Radiol., 40, 641.

Wendeberg, B., and Yamamuro, T. (1965). Acta orthop. scand., 36, 21. Williams, D. F., and Blahd, W. H. (1967). f. Urol., 97, 1070.

\title{
Post-partum Hypercalcaemia in Treated Hypoparathyroidism
}

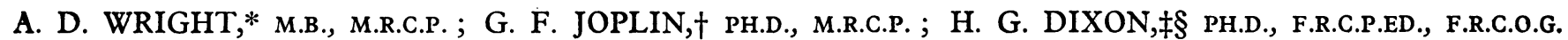

Brit. med. F., 1969, 1, 23-25

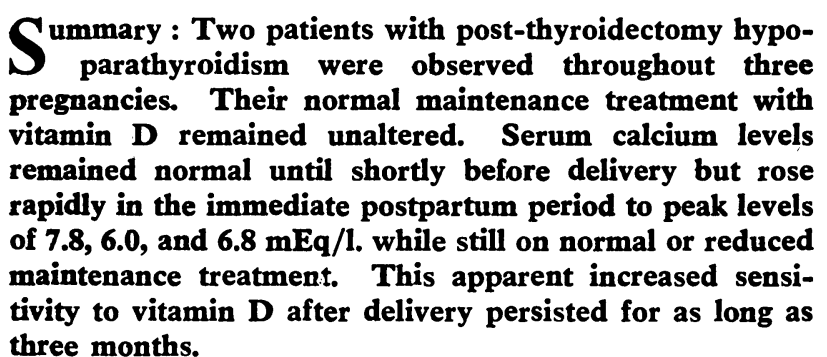

\section{Introduction}

This report concerns three pregnancies in two treated wellestablished hypoparathyroid patients in whom there was an unexpected and significant rise in serum calcium levels post partum.

\footnotetext{
* Medical Research Council Junior Research Fellow.

† Lecturer in Clinical Endocrinology and Consultant Physician.

¥ Lecturer and Consultant Obstetrician and Gynaecologist.

Royal Postgraduate Medical School and Institute of Obstetrics and Gynaecology, Hammersmith Hospital, London W.12.

5 Present address: Department of Obstetrics and Gynaecology, University of Bristol, Southmead Hospital, Bristol.

Treated hypoparathyroidism in pregnancy has not previously been noted to require any alteration in maintenance therapy (Anderson and Musselman, 1942 ; Graham et al., 1964 ; O'Leary et al., 1966). The level of serum calcium in these reported cases was carefully followed during the pregnancy and again at varying intervals afterwards, but not immediately post partum.

\section{Case 1}

Hypoparathyroidism became evident in this patient 24 hours after a nine-tenths thyroidectomy for juvenile thyrotoxicosis in 1957. Since then maintenance treatment with calciferol 100,000 units daily together with calcium Sandoz ( $57 \mathrm{mEq}$ of calcium daily) has kept the serum calcium within the normal range $(4.5-5.5 \mathrm{mEq} / 1$., venepuncture performed without stasis). Since 1957 she has remained euthyroid (normal neck uptake of radioiodine) and in good general health.

\section{First Pregnancy}

The first pregnancy occurred in 1964-5, when she was aged 23 years. No change was made in the maintenance therapy during this pregnancy, and frequent serum calcium levels showed no trend upwards or downwards, varying between 4.9 and $5.5 \mathrm{mEq} / \mathrm{l}$. 
(Fig. 1). The serum inorganic phosphate, alkaline phosphatase, and urea levels remained normal and unchanged. Twenty-four hours before the beginning of labour the serum calcium had risen to $5.6 \mathrm{mEq} / 1$. (Fig. 2). Labour was induced at term by artificial rupture of the membranes because of mild hypertension. The duration of the first stage of labour was three hours and the second stage two hours; the induction-delivery interval was five hours. A normal male infant was born, weighing $4,020 \mathrm{~g}$. To suppress lactation an injection of hexoestrol $15 \mathrm{mg}$. was given on the day of delivery and repeated on the following day.
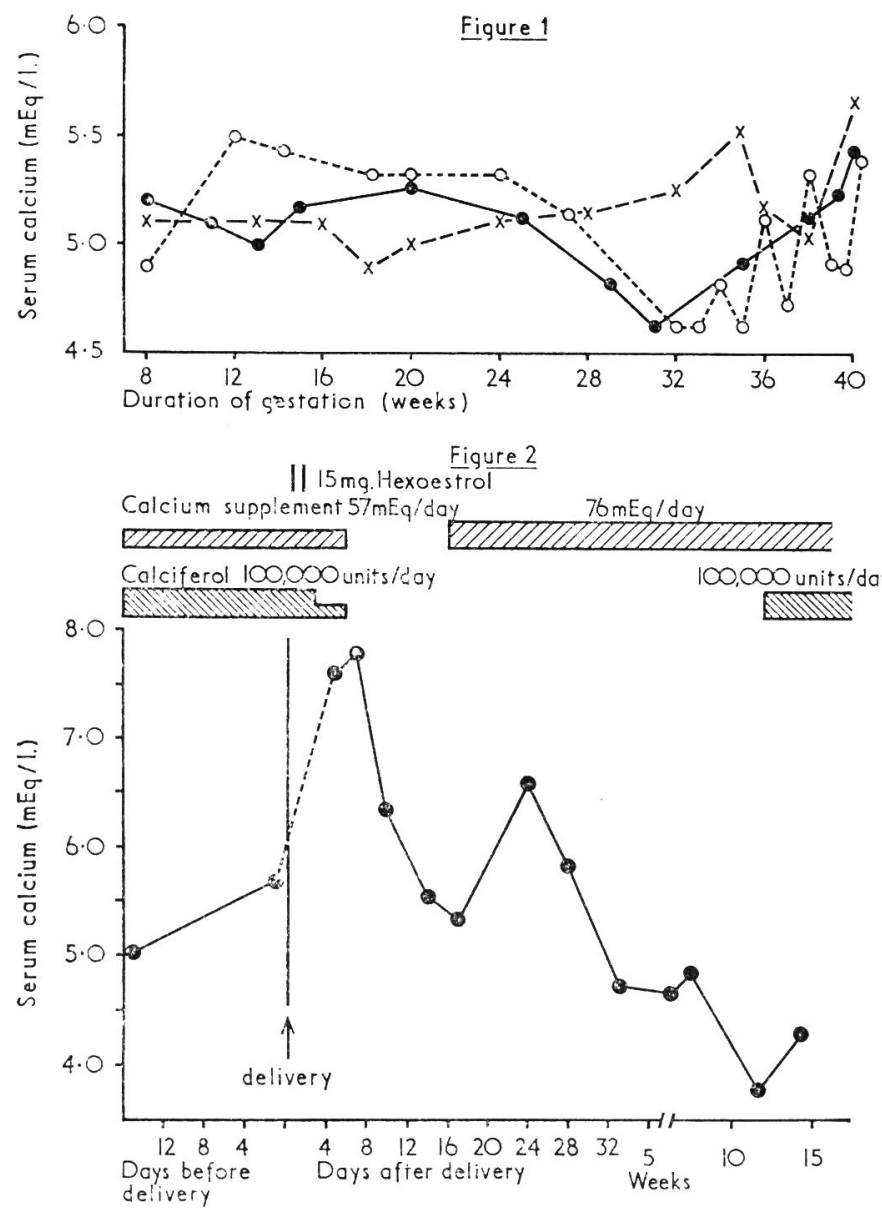

FIg. 1.-Serial serum calcium levels in three pregnancies in patients with hypoparathyroidism on constant calciferol therapy. $\times-\times$ Case 1 , first pregnancy; 0 - Case 2. Fig. 2. - Serum calcium before and after delivery. Case 1, first pregnancy.

The calciferol and calcium supplements were continued unchanged for the first three days after delivery, and for a further three days at a reduced dosage of calciferol of 50,000 units daily. On the fifth day after delivery weakness, lassitude, nausea, and thirst were noted and the serum calcium was found to be $7.6 \mathrm{mEq} / 1$. All treatment was immediately discontinued and the symptoms subsided, but the serum calcium levels did not fall to normal until the 17th day. During this period of hypercalcaemia there was a transient rise in blood urea to $60 \mathrm{mg} . / 100 \mathrm{ml}$. but the serum phosphate and alkaline phosphatase remained normal. Calcium supplements, $76 \mathrm{mEq}$ daily, were restarted on the 17th day, and again there was a rise of serum calcium levels, which was very temporary. The serum calcium was maintained within normal limits on treatment with calcium alone for a further three months, signs of hypocalcaemia not appearing for 15 weeks after delivery (serum calcium $3.8 \mathrm{mEq} / 1$.). This was corrected by reintroducing calciferol 100,000 i.u. daily, which again became satisfactory maintenance treatment.

\section{Second Pregnancy}

The second pregnancy occurred in 1967. Serum calcium levels again remained normal, 4.6-5.5 $\mathrm{mEq} / 1$., throughout pregnancy (Fig. 1) on the unchanged regimen of calciferol 100,000 i.u. daily and a calcium supplement of $76 \mathrm{mEq}$ daily. The inorganic phos- phate and alkaline phosphatase also remained normal. A normal female infant weighing 3,660 g. was born by spontaneous delivery at term. The first stage of labour lasted 12 hours and the second stage 15 minutes. Breast-feeding was not allowed but oestrogens were deliberately withheld.

A slight rise in serum calcium occurred 18 hours before the onset of labour and an acute rise to $6.0 \mathrm{mEq} / \mathrm{l}$. was seen during the first 24 hours after delivery (Fig. 3). All treatment was stopped at

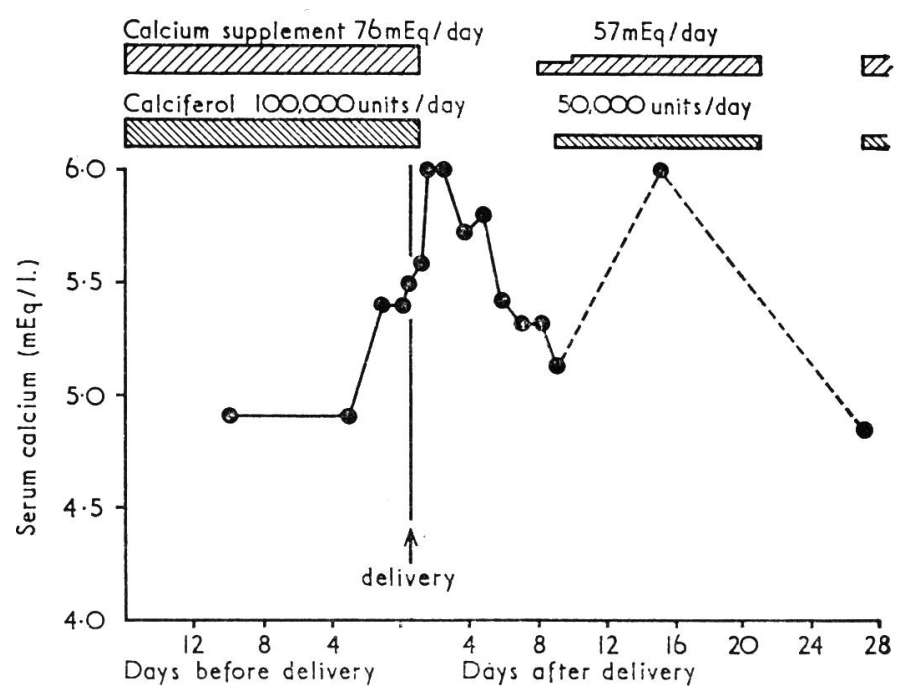

Fig. 3.-Serum calcium before and after delivery. Case 1, second pregnancy.

once and the serum calcium fell to $5.1 \mathrm{mEq} / \mathrm{l}$. over the next six days. Calciferol 50,000 i.u. daily and calcium supplements of 38$57 \mathrm{mEq}$ daily were then restarted, but hypercalcaemia $(6.0 \mathrm{mEq} / \mathrm{l}$.) with thirst and tiredness recurred, so all treatment was again discontinued after the 20th day post partum. One week later the serum calcium was normal $(4.8 \mathrm{mEq} / \mathrm{l}$.) and treatment was restarted a second time without a recurrence of hypercalcaemia, beginning with half her usual maintenance dosage for 12 days. Since then her full maintenance dose of 100,000 i.u. daily of calciferol and $76 \mathrm{mEq}$ of calcium has been given, with excellent control.

The cord plasma calcium of the baby was $6.0 \mathrm{mEq} / \mathrm{l}$. (the normal range given by Smith (1959) is $4.2-7.2 \mathrm{mEq} / \mathrm{l}$.).

\section{Case 2}

Hypoparathyroidism in this patient developed three days after a nine-tenths thyroidectomy for thyrotoxicosis in 1950 . Since this operation she has remained euthyroid. The first pregnancy at another hospital in 1961, when aged 32 years, was uneventful. Maintenance treatment with calciferol 150,000 i.u. daily was continued

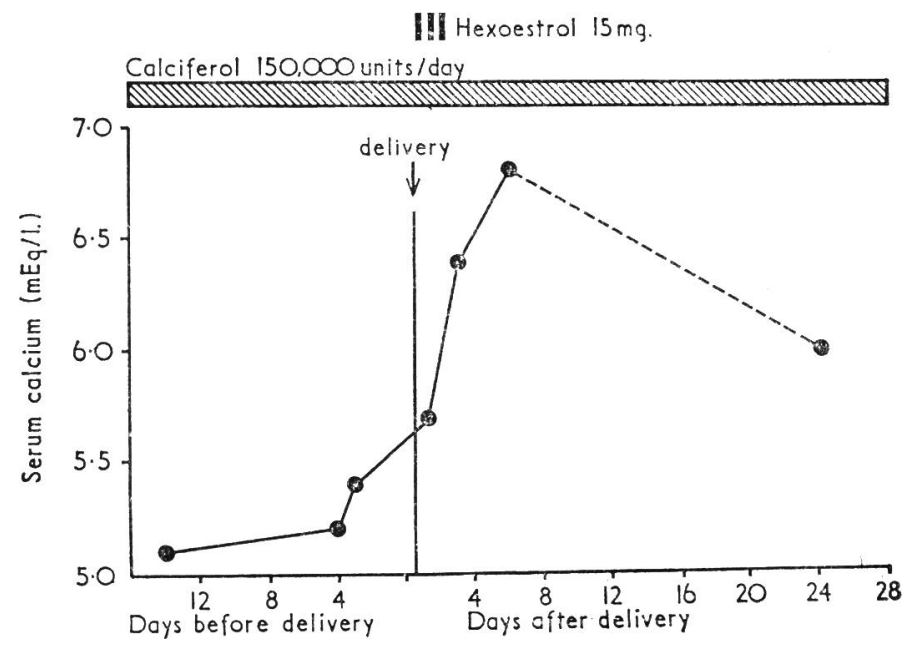

FIG. 4.-Case 2. Serum calcium before and after delivery. 
throughout that pregnancy and the puerperium, and lactation was suppressed. There were no symptoms of hypercalcaemia post partum, but the serum calcium was not measured until four months after delivery, when it was normal. Spontaneous miscarriages occurred in 1962 and 1963.

Pregnancy, 1964-5.-The serum calcium was measured frequently throughout this second pregnancy (Fig. 1). Calciferol 150,000 i.u. daily was taken regularly during gestation without calcium supplements, this being her usual therapy. The serum calcium levels showed no trend upwards or downwards in the antenatal period, varying between 4.6 and $5.4 \mathrm{mEq} / \mathrm{l}$. A normal infant weighing $3,325 \mathrm{~g}$. was delivered spontaneously at 39 weeks' gestation. The duration of the first stage of labour was five hours and the second stage 10 minutes. Hexoestrol $15 \mathrm{mg}$. was given intramuscularly on the day of delivery and on the subsequent two days to suppress lactation.

The serum calcium rose to $5.7 \mathrm{mEq} / \mathrm{l}$. on the first day post partum (Fig. 4), reaching $6.8 \mathrm{mEq} / 1$. on the sixth day. There were no hypercalcaemic symptoms. Calciferol 150,000 i.u. daily was continued throughout this post-partum period against advice. When she was last seen by us on the 24 th day the serum calcium had still not fallen to normal.

The cord plasma calcium of the baby was $5.8 \mathrm{mEq} / 1$.

\section{Discussion}

Both patients, who clearly had hypoparathyroidism following thyroidectomy, developed hypercalcaemia immediately after the delivery of their three babies while on their usual maintenance therapy. After both pregnancies in Case 1 the hypercalcaemia resulted in symptoms.

In previously described cases of pregnant women with treated hypoparathyroidism no changes in the serum calcium have been reported, though observations may not have been made in the immediate post-partum period. On the other hand, reports of untreated hypoparathyroidism have noted some temporary improvement during pregnancy and the immediate post-partum period (Grant, 1953 ; Rossi, 1960).

There are few reported studies of calcium metabolism in normal human pregnancy. Mull and Bill (1934) found a slight $(5 \%)$ fall in serum calcium levels in pregnancy which rose to normal during the first week post partum; hypercalcaemia was not found. These findings were confirmed by Newman (1947), and, in addition, Kerr et al. (1962) showed that the non-protein-bound fraction of the serum calcium remained unchanged. Goss (1962) noted a fall in the urine calcium excretion in late pregnancy under normal diet conditions; though an increase in calcium intake resulted in increased urinary excretion, the serum calcium levels showed little change. Calcium balances reported by Newman (1956) in four normal subjects showed a positive balance in pregnancy, but no similar studies have been reported for the puerperium.

At parturition there is a sudden fall in placental hormones, of which oestrogens or lactogen might affect calcium metabolism. Though the administration of oestrogen induces a fall in serum calcium (Young et al., 1968) the effect is small.
Placental lactogen, being similar to growth hormone, might induce hypercalcaemia, but is unlikely to do so on withdrawal.

The protracted period of hypercalcaemia shown by our patients is probably due to hypersensitivity to vitamin $D$. The importance of calcium absorption is suggested by Case 1, whose maintenance therapy in both pregnancies included oral calcium supplements, in that she had a more severe rise in serum calcium than Case 2, who was not taking extra calcium. Furthermore; temporary hypercalcaemia was induced when calcium supplements alone were restarted after the first pregnancy in Case 1, and indeed normal serum calcium levels were maintained for three months on this treatment before vitamin $\mathrm{D}$ was again necessary. It may be relevant that both patients had postthyroidectomy hypoparathyroidism, and hence may be deficient in thyrocalcitonin, which would normally oppose hypercalcaemia by inhibiting bone resorption (Martin et al., 1966). This would make them more susceptible to hypercalcaemia, but at the moment it is not clear why parturition should even precipitate the hypercalcaemia.

Clearly the practical point that emerges from the studies done on our two patients is that in such cases the serum calcium should be watched very closely as the time of delivery approaches, so that immediate withdrawal of vitamin $\mathrm{D}$ may be effected at the first sign of a rise in serum calcium. If the study of further cases shows a similar pattern it may emerge that routine withdrawal of vitamin $\mathrm{D}$ well before delivery, say at the 38th week, is indicated. On the other hand, the foetus must not be exposed to a period of maternal hypocalcaemia, lest neonatal hyperparathyroidism should occur (Aceto et al., 1966).

All maternal serum calcium estimations were performed by the Department of Chemical Pathology, and we are indebted to Dr. Ruth Haslam. The serum calcium levels of the cord blood were estimated in the Institute of Child Health, Hammersmith Hospital. Professor G. S. Gordan kindly referred Case 2 and supplied the previous medical details. We are grateful to Professor Russell Fraser for helpful criticism of the manuscript.

\section{REFERENCES}

Aceto, T., Batt, R. E., Bruck, E., Schultz, R. B., and Perez, Y. R. (1966). f. clin. Endocr., 26, 487

Anderson, G. W., and Musselman, L. (1942). Amer. F. Obstet. Gynec., 43, 547 .

Goss, D. A. (1962). Obstet. and Gynec., 20, 199.

Graham, W. P., Gordan, G. S., Loken, H. F., Blum, A., and Halden, A. (1964). ' f. clin. Endocr., 24, 512 .

Grant, D. K. (1953). Quart. F. Med., 22, 243.

Kerr, C., Loken, H. F., Glendening, M. B., Gordan, G. S., and Page, E. W. (1962). Amer. F. Obstet. Gynec., 83, 2.

Martin, T. J., Robinson, C. J., and MacIntyre, I. (1966). Lancet, 1, 900.

Mull, J. W., and Bill, A. H. (1934). Amer. F. Obstet. Gynec., 27, 510.

Newman, R. L. (1947). Amer. F. Obstet. Gynec., 53, 817.

Newman, R. L. (1956). Obstet. and Gynec., 8, 561.

O'Leary, J. A., Klainer, L. M., and Neuwirth, R. S. (1966). Amer. 7. Obstet. Gynec., 94, 1103.

Rossi, R. (1960). Riv. Clin. Pediat., 66, 417.

Smith, C. A. (1959). The Physiology of the Newborn Infant, 3rd ed., p. 297. Oxford. Young, M. M., Jasani, C., Smith, D. A., and Nordin, B. E. C. (1968). 